\title{
Cassava Value Chain as Instrument for Economic Growth and Food Security in Nigeria
}

\author{
Udemezue J. C. ${ }^{*}$, Chinaka E. C., Okoye, B. C. \\ National Root Crops Research Institute, Nigeria
}

Received December 18, 2018; Revised April 25, 2019; Accepted May 5, 2019

\begin{abstract}
Copyright $@ 2019$ by authors, all rights reserved. Authors agree that this article remains permanently open access under the terms of the Creative Commons Attribution License 4.0 International License
\end{abstract}

\begin{abstract}
Investment in agricultural sector anchors economic growth of a country which brings about food security. Agricultural sector is a strong driver of the Nigerian economy. It employs about $70 \%$ of the nation's labour force and has the capacity to alleviate poverty and ensure food security. This paper reviewed the cassava production trends, cassava value chain issues, value chain and the challenges for cassava production and processing in Nigeria. The paper recommends that the extension linkage with research should be strengthened so as to facilitate the spread of improved cultivars and management practices to farmers. The involvement of more cooperative societies in the multiplication and sales of stems should be encouraged. Integration of information and supply of various inputs is necessary. A group approach to extension delivery should be further promoted and the use of existing and new cultivars should be made popular through an extended or expanded cassava multiplication programme. Effective strategies are needed for stakeholders to share their experiences with those of other countries of the sub region who are participating in the processing of cassava. Cooperation linkages are needed with other important stakeholders like agricultural research, microfinance institutions, quality standards organizations, and equipment fabricators.
\end{abstract}

Keywords Cassava Value Chain, Economic Growth, Food Security Issues

\section{Introduction}

The agricultural sector in Nigeria is a very strong driver of the economy. The sector employed about $70 \%$ of the nation's labour force. It has the capacity and key to poverty alleviation and food security in the country. , more than $74 \%$ of the farming population in Nigeria consists of smallholder farmers, each of them owns or cultivates less than 5 hectares of farm land (Ojeka, Effiong and Eko- Eko, 2016). However, less than $50 \%$ of the country's cultivable agricultural land is under cultivation. Even then, smallholder and traditional farmers who use rudimentary production technologies dominated it and this resulted to low yield in Nigeria.

Nigeria is the largest producer of cassava tuber in the world with average annual production of about 35 million $\mathrm{mts}$ over the last five years (Ayodele Andre, Nnennaya, Chijioke, Gianiat and Lateef, 2011). Currently, average annual output from cassava stands at about 54 millionmts due to governmental policy on food importation and this will keep on moving since more capable hands engage in cassava production. However, about one-third of the total national output comes from Niger Delta region where many livelihoods depend on cassava as a main source of food and income. According to Ayodele et al (2011), it has been estimated that the number of small commercially oriented cassava producers within the Niger delta region would be in the range of 70,000-120,000 (out of the more than one million producers) and over 400-500 cooperatives and cottage industries, 800,000 - 950,000 traders, 46 small medium processing industries and one large processing industry in the region. Since Niger Delta region alone can contribute significantly to Nigeria economy up to this output, this implies that cassava value chain can be of the major engine for economic growth and poverty reduction in Nigeria if the potentials are properly harnessed.

The importance of cassava to the livelihoods of many millions of the poor people has made the crop a target for intervention (Anyaegbunam, Asumugha, Olojede and Ajuka, 2016). The potential of the crop is numerous because it offers the cheap source of food calories and the highest yield per unit area. Cassava has multiple roles as famine reserve, food and cash crop, industrial raw material and livestock feed (Osipira-Patino and Ezedinma, 2015). Across the country, cassava production has undergone a tremendous increase for different reasons, specifically due to introduction of high yielding and disease-resistant 
varieties, early maturiing ones, among other factors (Sanni, Onadipe, Ilona-P, Mussagy, Abssa, and Dixon, 2009).

The global food security index which evaluated a country's ability to feed people on the basis of the key determinants of food security in terms of affordability, availability and quality in 2011, ranked Nigerian as the $80^{\text {th }}$ food unsecured nation out of 105 countries studies. However, about $65 \%$ of Nigerians are food insecure, which means that they do not have sufficient access to the amount and variety of food for a healthy and productive life, $64 \%$ of the population is reported as living below the international poverty line of $\$ 1.25$ per day (UNICEF, 2010). The current status of food insecurity in Nigeria has a link with the consequence of a very long neglect of the agricultural sectors by the various governments in the country, but with the advent of cassava value chain and other food crops, the aforesaid problems could be eliminated.

Food security guarantees all human beings physical and economic access to the basic foods needed to lead active and healthy lives. Cassava value chain has the ability to transform a country from poverty state to self-enrichment through employment and income generation, especially at the stages of production, processing and industrial utilization (Anyaegbunam,et al, 2016).

This implies that increased generation of employment which is required for growth lies with increased industrial processing and utilization of cassava for expanded production of non-food and non-competitive industrial products of cassava that are competitive to penetrate export markets. With this, opportunities to generate increased income and employment will be enormous and diversified. In view of this, this paper, therefore, assessed cassava value chain and economic growth with respect to food security in Nigeria (Anyaegbunam,et al, 2016).

\section{Cassava Production Trends in Nigeria}

The productivity and growth rate of root and tuber crops in Nigeria has been increasing tremendously for the past two and half decades, but such increase has not been meeting with the rising food demand as a result of high population pressure and poor infrastructural facilities to increase processing into food forms (Eke-Okoro, Njoku, Mbe, Awa, Amanze and Eke-Okoro, 2010). However, the contributors to this trend in food production include the root and tuber crops sector with increasing annual output and growth rates. Food and Agricultural Organization (FAO, 2009) estimated a yearly output of 45 million metric tons for cassava while other root and tuber crops like yam, sweetpotato, potato, cocoyam and ginger contributed yearly output of 32, 1.3, $0.73,5.0$ and 0.223 million metric ton respectively.

Cassava production in Nigeria is by far the largest in the whole world, it is a third more than cassava production in Brazil and most importantly double the production of Indonesia and Thailand. Production of cassava in some other African countries such as the Democratic Republic of Congo, Ghana, Madagascar, Mozambique, Tanzania and Uganda are smaller in comparison to substantial out in Nigeria.

According to food and agricultural organization (FAO, 2004), cassava production in 2002 in Nigeria was estimated to 34 million tones, the trend for cassava production reported by the Central Bank of Nigeria mirrored the FAO data until 1996 and thereafter rises to the highest estimate of production at 37 million tones in 2000. The third series provided by the project coordinating unity (PCU) had the most conservative estimate of production at 28 million tones in 2002. (PCU, 2003). However, over 90\% of cassava produced in the country is consumed locally with less than $10 \%$ utilized for industrial purposes.

Cassava is one of the world's most important food crops with annual tons in 2003. However, the top production countries globally in 2013 were; Nigeria accounting for $19 \%$ of the total, Thailand accounting $11 \%$, Indonesia accounting for 9\%, brazil (8\%) and Democratic Republic of Congo which also accounts for $6 \%$ respectively, from all indications, Nigeria appeared to be the most leading country in cassava production (Sanginga, 2015). Since 2004-2017, the production of cassava trend has been moving upwards with a slight decline in production and this has been as a result of global demand for the commodity as a food security crop for growing populations in emerging markets as well as industrially processed cassava product. Despite the above, Africans account for less than $1 \%$ of total exports of cassava product, this is because cassava production is dominated by smallholder farmers, (25\% women). Hence, cassava production is seen as masculine occupation in many African countries. The root crop is a source of livelihood for at least 300 million people. Virtually about $90 \%$ of cassava produced in Africa is used as staple food for human consumption. However, expansion of cassava production in Nigeria has relatively steady since 2009 with an additional push between the years 2010 to 2016 as a result of the release of improved cassava varieties by international institute for tropical agriculture (IITA) and other related research institutes that see cassava as one of their mandate crops(Sanginga, 2015).

According to FAO (2009) and Eke-Okoro et al (2014), the growth rate of cassava production showed some upwards movement at $1766 \mathrm{mmt}$ from 1975-1979. From 1980-1984 cassava production stood at $2724 \mathrm{mmt}$. In 1985-1989 it was at $14542 \mathrm{mmt}, 1990-1996$ it became 20784 which indicated some upward movement. In 1997-1998, the country produced about 34092 metric tons of cassava with growth rate of $2.4 \%$, between2009-2011it was reduced to 45000 metric tons with zero growth rate. Within the intervals of 2012-2013, the trends of cassava production became stagnant and later started increasing 
with 3.2\% growth rate. From 2014 to 2015, there is a tremendous increase in annual output (23590) with 60.3\% growth rate which could be attributed to the government support on agriculture just to attain the food security nation as well as agricultural transformation agenda of the present administration. Table 1 below shows cassava production trends in Nigeria from 1975-2015(FAO 2009, FAO, 2010 and Faostat (2016).

Table 1. Cassava production trends in Nigeria from 1975-2015

\begin{tabular}{|c|c|c|}
\hline Year & $\begin{array}{c}\text { Cassava Annual Output } \\
\text { (mmt) }\end{array}$ & Growth Rate (\%) \\
\hline $1975-79$ & 1766 & 10.8 \\
\hline $1980-84$ & 2724 & 10.8 \\
\hline $1985-89$ & 145442 & 80.8 \\
\hline $1990-96$ & 20784 & 6.1 \\
\hline $1997-98$ & 34092 & 2.4 \\
\hline $2009-11$ & 45000 & - \\
\hline $2012-2013$ & 20395 & 3.2 \\
\hline $2014-2015$ & 23590 & 60.3 \\
\hline
\end{tabular}

Source, FAO 2009, FAO, 2010 and Faostat (2016)

\section{Cassava Value Chains and Food Security Issues in Nigeria}

Cassava is one of most important crop for Nigerian farmers and is mostly widely cultivated crops that provide food and income to over 30 million farmers, large numbers of processors and traders (Daniel, Udah, Elechi, Oriuwa, Tijam, Grand Sanni, 2011). However, studies have proved that cassava has the potential and ability to industrialize Nigeria more than any other crops provided that its potential is properly harnessed. Awoyinka (2009) is of the view that Nigeria can earn about US 85 billion per annum from cassava and its by-products, thus, making it a key foreign exchange earner, instrument for job creation and catalyst for development.

Internal trade in cassava is increasing and trade volumes between 1995 and 2005 have shifted by about 36\% and a conservative projection of the cassava trade for the year 2015 at a $40 \%$ growth rate is estimated at 11.76 million mt. globally, the traditional use of cassava is changing from primarily human consumption to processing into industrialized products such as starch, flours and ethanol. Philips, Taylor, Sanni and Akoroda (2004) revealed that on the average, about $45 \%$ of the respondents in the Niger Delta state consume cassava meal more than four times a week and also see cassava as their main source of income for many rural economies in Nigeria. Therefore, sale of cassava is an important source of income to rural households in Nigeria. According to FAO (2005), income generated from cassava production contributed about $34 \%$ to the total household farm income of cassava farmers in Imo state alone. Hence, cassava marketing is an important source of income to rural household in Nigeria.

Cassava value chains provide comprehensive information on the cassava production and processing as a guide for future and investment in the sector. Investment in cassava sector is more benefit than other sectors in Nigeria since it has potentials to alleviate a nation from poverty states. Cassava value chain comprises input suppliers, farmer's/farmers' cooperatives, processors, traders, collectors, intermediate and final consumers within and outside the region. Cassava is now one of the priority crops to be used as a spring board to wriggle out of the menace of unemployment in the country since its production is increasing at 3 percent every day. Therefore, cassava value chain has the capacity to create new jobs and generate increased income and employment in the economy if properly harnessed.

The quest for food security as a prerequisite for human happiness has far back noted in the history of agriculture in Nigeria. Since 1960, Nigerian government has been striving to be one of the food secured nations, yet they have not been able to achieve it. The food self-sufficient ratio fell from $98 \%$ in early 1960 s to less than $54 \%$ in $1986,18 \%$ of the population (14.4 million) was estimated to be critically food insecured in 1990 and increased to 36\% (32.7 million) in 1992 and 40.7\% in 1996. The country's food security status keeps increasing and the recent estimates put the number of hunger people in Nigeria at over 53 million, just less than $30 \%$ of the country's total population estimated at 160 million (Babatunde, 2005, and Azubuike, 2012). However, the current status of food security in Nigeria may be linked to the consequence of a very low neglect of the agricultural sectors by various governments in power. The global food security index which evaluated a country's ability to feed its people on the bases of the key determinants of food security like affordability, availability and quality in 2011, however, ranked Nigeria as the $80^{\text {th }}$ food insecured nation out of 105 countries studied. About $65 \%$ of Nigerians are food insecured, that is, do not have sufficient access to the amount and variety of food for a healthy and productive life; $64 \%$ of its population is reported as living below the international poverty line of $\$ 1.25$ per day (UNICEF, 2010).

In view of the above, Agricultural Transformation Agenda (ATA) rest its oasis on the fortunes of root and tuber crops just to make Nigeria a food security nation. Since cassava crop plays a significant role in the agricultural production, income generation and employment creation in Nigeria if the potentials are properly harnessed. The implication of this is that cassava value-chains are essential for economic development and employment generation, which could at the same time foster revolution in the agricultural sectors as well as 
encouraging in the growth of Nigerian economy. Therefore, investment in agricultural sector anchors economic growth of a country, and economic growth brings about food security of a nation that leads to human happiness in totality.

According to Oni Timothy Olukunle (2013). There are employment generations at the various levels of cassava value chain and understanding how employment is distributed along cassava value chain provides the necessary start to determine opportunities for employment creation. Therefore, in cassava value chain, individual actor participated in number of different value chains at the same time such that a cassava farmer may be involved in various agricultural crops and several handcraft activities as a means of income diversification. In the same way, a trader might be involved in trading multiple agricultural products at the same time or different time depending on the season.

\section{The Value Chain for Cassava Production and Processing in Nigeria}

Cassava production in Nigeria is carried out mostly by small holder farmers. There are also a few medium and large-scale producers of cassava in the country. After harvest, small holder farmers sell their fresh cassava root to assemble traders and their intermediaries to sell in the local market or consumption. However, assemble traders supply fresh cassava roots as a raw material to some processing industries to convert the fresh roots into finished product. Moreso, medium and large scale producers of cassava, may sometimes, sell their produce directly to the processors who make products such as gari, fufu, starch among others which are sold in local market or international market as an export. This can be represented diagrammatically in Fig. 1 below.

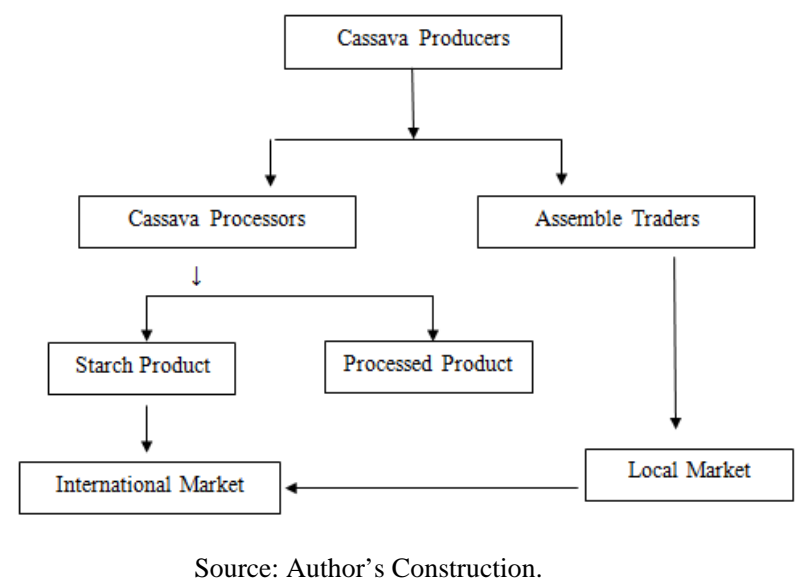

Figure 1. Shows value chain for cassava production and processing in Nigeria

\section{Challenges of Cassava Production and Processing in Nigeria}

Despite the potentials, there are still some challenges to the development of the cassava subsector in Nigeria. According to (FAOSTATS, 2015), the major challenges to the development of the cassava subsector in Africa include the following:

Low yields: The yields of African cassava producers are 37 - 64\% below the global value. In 2013, Nigeria reached 14.1 tons/ha, similar to Brazil but $\sim 37 \%$ less than Indonesia (22.5 tons/ha) and Thailand (21.8 tons/ha).The yields of the other top African producers are also low. Cameroon's cassava yield in 2013 was at $14.7 \mathrm{MT} / \mathrm{Ha}$, while Angola achieved yields similar to those of Nigeria at 14.1 tons/ha. DRC's 2013 yield was 8.0 tons/ha, less than $60 \%$ of Nigeria's yield. Yields are low by global standards, mainly due to the prevalence of traditional subsistence farming techniques with little or no use ofinputs.

Fragmented, smaller-holder farms: In Africa, cassava production is carried out in predominantly smaller-holder and fragmented farms with rudimentary technologies, low use of inputs limited economy of scale. Six million small-scale farmers account for $90 \%$ of the production in Nigeria.

Limited adoption of improved seeds: Small-scale farmers rarely use improved planting materials (clean, healthy seeds), and the sub-sector is dominated by disease-prone local varieties with long maturation periods and low yield potential. IITA and African research institutes have played leading roles in the development of improved cassava varieties that are multiple disease and pest resistant, early maturing, and high yielding. These varieties have the potential to raise productivity by up to 30-40 tons/ha. Thirty-two African countries have released an estimated 384 high yielding varieties between 1970 and 2014. These varieties are high yielding with good levels of multiple disease and pest resistance as well as of acceptable quality for food, feed and industrial uses in Africa. While the combination of these new varieties and better agronomic practices could increase yields per unit area by at least $40 \%$, the rate of adoption by smallholder farmers has been low. The dissemination of these varieties has often suffered from the lack of a reliable planting material distribution system from National Agricultural Research Systems (NARS) because of weak extension systems, insufficient quantities of planting material, and delays in distributing the approved planting materials. This compels farmers to continue to grow local, low yielding varieties. This is exacerbated by inadequate location specific knowledge on fertilizer use, and other cultural practices such as weed and pest and disease management for cassava systems and late planting specifically in southern Africa region where maize comes first. Private companies are also not involved in distribution because cassava is propagated vegetatively, and it takes one year to produce cassava 
planting material compared to three to five months for grain seeds.

Low use of herbicides: Low use of herbicides and pesticides presents another obstacle. In the case of south-eastern Nigeria, only 3\% of farmers use herbicides because they do not know about them, lack the technical skills to use them, are not able to afford them or are under pressure from local NGOs to avoid them. When they do use them, most use insufficient amounts of herbicides to save cost. Instead increasing herbicide use would reduce the need for weeding and free up labor for other activities.

Limited use of fertilizers and irrigation: Fertilizers are used infrequently, and even when used, the amounts are below the recommended levels because of the high cost. Use of irrigation techniques is also a constraint in almost all cassava farms in Africa as the system of cultivation is predominantly rain-fed.

High labor use: Cassava farming is highly labor-intensive and related costs can account for up to $90 \%$ of total production costs. For example, the cost of developing and preparing land is quite high. In Oyo and Benue states of Nigeria, $98 \%$ of the average cassava production cost of USD 700 per hectare is labor (ridging, planting, weeding, etc.) and $2 \%$ is inputs (fertilizers, seeds).

Low use of mechanization: Small-scale cultivation is characterized by a low level of mechanization. For example, tractors are used in just $10 \%$ of Nigeria's cassava cultivation. Harvesting is done manually and is therefore time-consuming and expensive. In both small- scale and commercial farming, $8-12 \%$ of cassava roots are lost due to sub-optimal harvesting methods. A survey conducted by the African Agricultural Technology Foundation (AATF) during the 2004 Triennial Symposium of the International Society for Tropical Root Crops - Africa Branch revealed a consensus among African cassava experts that the most important intervention to increase the competitiveness of the cassava industry was the adoption of mechanization in cassava production. Such mechanization will enable a reduction of labor costs, thus bringing down the cost of cassava as a raw material and stimulating reliance on local cassava as a competitive raw material for various industries.

High Prices of Cassava Roots: Cassava prices vary greatly from country to country as there is no global commodity market and production costs differ vastly due to varying levels of input use. For example, in 2012, the average price for cassava was USD 161/ton in Nigeria (10\% mechanized), and USD 67/ton in Thailand (highly mechanized). Cassava derived products must be price-competitive with their substitute products like corn starch and ethanol made from other sources.

Limited access to finance: Both commercial and smallholder farmers have limited access to finance. In Nigeria the agricultural sector accounts for $42 \%$ of GDP but has $2 \%$ of all formal credit flows. Reasons for this include: conditions to access a bank loan are stringent; interest rates are high (17-25\%); and commercial banks do not offer conducive payment terms for agro- based activities (e.g., fixed repayment periods that may not match annual cropping, especially when loan release is not coordinated with growing cycles). As a result, commercial farmers may produce lower volumes.

Trade and transport: Smallholder cassava producers have weak and limited access to markets. The high transportation costs and the need to process cassava within 48 hours of harvesting because of its perishability, makes small producers to sell most of their product at local markets. The high fragmentation (scattered farms) and poor infrastructure make it difficult to develop commercial-scale aggregation. Poor roads and inadequate storage facilities drive up prices and increase postharvest losses.

Weak access to markets: Agricultural markets world-wide are characterized by market structures, both quantitative - aggregation, storage, and processing facilities, and qualitative - quality standards, information services, logistics for distribution of agricultural products. Many of these structures do not exist in many African countries for cassava distribution.

On other hand, Sanni, Onadipe, Ilona.Mussagy, Abass, and Dixon (2009) saw the challenges of cassava production in Nigeria as follows; High production cost of cassava-based products from price fluctuations and limited sources of supply. Poor and inadequate infrastructural facilities, bad road network and irregular water supply. Most farmers and industrialists find it impossible to get loans from the Banks. The few that have the opportunity are limited because of the high interest rate. Inconsistent policy has adversely affected the Nigerian cassava industry so much that willing investors are discouraged while some in the business are folding up. Easy access to alternative products through importation, e.g., starch. The industries using starch reported that they found it easier to import corn starch than starch from cassava that is not readily available to use when they need it. Lack of a good market information system to create a network among the stakeholders, in Nigeria. Poor capacity building of the processors: especially the women who are in the forefront of cassava processing. The women are not empowered for the enterprise.

\section{Conclusions}

The agricultural sector is the power house upon which other economies depend for their development. The sector has witnessed several challenges since the colonial and post independence years as a result of government 'lackadaisical attitude towards farming system. The condition of the sector in Nigeria today is deplorable, despicable, retrogressive and not even befitting a nation 
that is rich and blessed with abundant natural resources. In view of these, the authors have researched to do justice with the following issues; cassava production trends in Nigeria, cassava value chain and food security issues in Nigeria, value chain for cassava production and processing in Nigeria. With respect to these, this paper reviewed the cassava production trends in Nigeria, cassava value chain issues in Nigeria, value chain for cassava production and processing and the challenges of cassava production and processing in Nigeria.

\section{Recommendations}

Government should create a conducive environment by increasing the budgetary allocation for cassava transformation agenda, friendly policies framework for strong and efficient agricultural sector that can accelerate the attainment of Nigeria's dream of achieving the targeted growth rate and the proposed vision of becoming one among the 20 world leading economies by the year 2020 . The extension linkage with research should be strengthened so as to facilitate the spread of improved cultivars and management practices to farmers. The involvement of more cooperative societies in the multiplication and sales of stems should be encouraged. Integration of information and supply of various inputs is necessary. A group approach to extension delivery should be further promoted and the use of existing and new cultivars should be made popular through an extended or expanded cassava multiplication programme. Effective strategies are needed for stakeholders to share their experiences with those of other countries of the sub region who are participating in the processing of cassava. Cooperation linkages are needed with other important stakeholders (agricultural research, microfinance institutions, quality standards organizations, and equipment fabricators)

\section{REFERENCES}

[1] Awoyinka, Y.A. (2009). Cassava marketing: Option for sustainable agricultural development in Nigeria. Ozean Journal of Applied Science 2(2):175-183 http://ozelacademy.com/ojAsv² $n^{2} 5$ pdf.

[2] Ayodele, D., Andrew, U., Nnennaya, E. Chijioke, O. Gianiat, T. and Lateef, S. (2011). Cassava Value Chain Analysis in the Niger Delta. Foundation for Partnership Initiatives in the Niger Delta.

[3] Azubuike, G. (2012). Nigerian food Security as a time bomb. Retrieved online at http:allafrica.com.stories/201231/093.ht ml A.E.Obayelu@A.O. Obayelu.2012.

[4] Babatunde, R.O. (2005). Food Security and marketing Problems in Nigeria: The case of maize marketing in Kwara State. International Conference on Research for Development in Agricultural Forestry, Food and National
Resources management.

[5] Daniel, A. Udah, A, Elechi, N., Oriuwa, C. Tijam, Grand Sanni, L. (2011). Cassava Value Chain Analysis in the Niger Delta. Foundation for Partnership Initiatives in the Niger Delta pp 1-11.

[6] Edem, I.D. and Nkereuwem, M.E. (2015). Crucial roles of tuber crops and the development activities in the global food system. American Journal of Agricultural Science Vol. 2(2) pp. 42-49.

[7] Eke-Okoro, O.N., Njoku, D.N. Mbe, J.O. Awah, J.I. Amanze, N.J. and Eke-Okoro, O.C. (2014). Contribution of Root and Tuber Crops in the Agricultural Transformation Agenda in Nigeria. ARPN Journal of Agricultural and Biological Science. Vol. 9, No.8.

[8] Food and Agricultural Organization (2009) Production year book for 2009. Food and Agricultural Organization, Rome, Italy.

[9] Food and Agricultural Organization (2010). Production year book for 2010. Food and Agricultural Organization.

[10] Food and Agricultural Organization (2004). Online Statistical Data Base. Rome, Italy: Food and Agricultural Organization of the United Nations. Website, www.fao.org.

[11] Ojeka, G.O. Effiong, C.E. and Eko Eko O. (2016) Constraints to Agricultural Development in Nigeria. International Journals of Development and Economic Sustainability- Vol. 4, No. 2, pp. 19-33.

[12] Oni Timothy Olukunle (2013). "Evaluation of Income and Employment in Nigerian Agricultural Sector”, Asian Journal of Agriculture and Rural Development, Vol. 3, No. 3, pp. 79-92.

[13] Ospira-Patino, M.T. and Ezedinma, C.I. (2015). Understanding the Linkage of Urban and Rural Markets of Cassava Production in Nigeria. African Journal of Agricultural Research (AJAR) 10(40): 3804-3813.

[14] Phillips, T.D.S. Taylor, L., Sanni and Akoorda, m. (2004). A Cassava Industrial Revolution in Nigeria. The Potential for a new Industrial Crop. IFAD/FAO, Rome 43 pp.

[15] Project Coordinating Unit PCU (2002). Crop Area Yield Survey, Abuja; Federal Ministry of Agriculture and Rural Development.

[16] Sanginga, N. (2015). Root and Tuber Crops (Cassava, Yam, Potato and sweetpotato). An Action Plan for African Agricultural Transformation. Pp. 2-3.

[17] Sanni, L.O., Onadipe, O.O., Ilona-P Mussagy, M.D., Abssa, A. and Dixon, A.G.O. (2009). Success and Challenges of Cassava Enterprises in West Africa: A Case Study of Nigeria, Benin and Sierra Leone. IITA, Ibadan, Nigeria.

[18] Tiri, G.D., Ojoko, E.A. and Aruwayo, A. (2014) Growth Enhancement Support Scheme (GESS) and the Challenges of Food Security in Nigeria. Biological Science Vol. 9, No. 7, pp. 226-227.

[19] UNICEF (2010). Statistics on Nigeria. Retrieved online from http://www.unicef.org/infobycountry/nigeriastatistics. htm.

[20] Sanni, L. O. Onadipe, O. O. Ilona, P. Mussagy, M. D. Abass, A. and Dixon A. G. O (2009). Challenges to cassava enterprises in West Africa Successes and challenges of cassava enterprises in West Africa:a case study of Nigeria, Bénin, and Sierra Leone. IITA, Ibadan, Nigeria. Pp19. 